providing excellent care at a reasonable cost. In addition, to keep your job, you must deal proactively with potential problems and communicate openly with physicians, nurses, directors of other departments, and your supervisor.

\section{SUMMARY}

Your skills as a hospital epidemiologist are extremely valuable and, when used properly, improve patient care. If you believe in your value, you will demand appropriate recognition and reimbursement. It is the right thing to do! After all, as George Bernard Shaw once said, "A day's work is a day's work, neither more nor less, and the man who does it needs a day's sustenance, a night's repose, and due leisure, whether he be painter or plough-man." 3

\section{REFERENCES}

1. Membership survey. SHEA Newsletter 1996;6:5.

2. Medical Group Management Association. Physician Compensation and Production Survey: 1995 Report Based on 1994 Data. Englewood, CO: MGMA; 1995.

3. Shaw GB. Webster's Book of Quotations. New York, NY: PMC Publishing Co; 1994:239.

\section{RECOMMENDED READING}

1. Gross PA. The future of the hospital epidemiologist in the 1990s: presidential address, SHEA annual meeting. April 1994. Infect Control Hosp Epidemiol 1995;16:179-182.

2. Karrass CL. The Negotiating Game. Rev ed. New York, NY: HarperCollins Publishers, Inc; 1992.

3. Simmons BP, Parry MF, Williams M, Weinstein RA. The new era of hospital epidemiology: what you need to succeed. Clin Infect Dis 1996;22:550-553.

4. Wenzel RP. Instituting health care reform and preserving quality: role of the hospital epidemiologist. Clin Infect Dis 1993; $17: 831-836$

\title{
Foege Named Professor
}

\section{Gina Pugliese, RN, MS Martin S. Favero, PhD}

William H. Foege, MD, MPH, became a professor in the Department of International Health at Emory University's Rollins School of Public Health as of February 1997. In his new position at Emory, Dr. Foege will write and teach in the rapidly growing Rollins School. Dr. Foege is best known to the infection control community because of his tenure as director of the CDC from 1977 to 1983 . He was executive director of The Carter Center from 1987 to 1992 . Since 1992 , he has been a Fellow for Health Policy at The Carter Center. He will continue as a Fellow and as senior health advisor to The Carter Center. In addition to holding the top positions at the CDC and The Carter Center, Dr. Foege is best known for his work in the global eradication of smallpox in the 1970s. More recently, The Carter Center has been instrumental in an international effort to eradicate Guinea worm disease, which would be only the second disease to be vanquished completely. His eloquent and insistent voice also has brought child survival and development, disease prevention, injury control, tobacco-related diseases, and other issues to the forefront of domestic and international health policy. 